\title{
VALORIZAÇÃO DA ENFERMAGEM E A PANDEMIA: ISSO TAMBÉM VAI PASSAR?
}

\author{
Bruna Duarte \\ Cristiane Damiani Tomasi \\ DOI: http://dx.doi.org/10.18616/intcov72
}

A Organização Mundial da Saúde (OMS) definiu 2020 como um grande marco para enfermagem, instituindo-o como ano internacional dos profissionais de enfermagem e das parteiras. Além disso, o ano marca o bicentenário do nascimento de Florence Nightingale, fundadora da enfermagem moderna. Segundo a OMS, o objetivo é valorizar e promover o trabalho realizado pela enfermagem. Essa decisão foi anterior à covid-19; não se imaginava que a enfermagem, justamente no ano em sua homenagem, seria mais necessária e valorosa do que a própria campanha da OMS buscava lembrar.

A história da enfermagem traz alguns elementos que mostram o protagonismo da profissão em diferentes cenários caóticos, como a própria Florence, durante a Guerra da Criméia, em que sua atuação permitiu uma redução de $80 \%$ para $2 \%$ de óbitos dos soldados feridos. Entretanto, a profissão esteve invisibilizada por muito tempo, sendo desprestigiada, desvalorizada, questionada sobre sua capacidade técnica científica.

Em outros países, como a Inglaterra, terra de Nightingale, a enfermagem está entre as profissões mais respeitadas. No Brasil, em meio à pandemia, enfermeiros e enfermeiras são ameaçados e agredidos durante protesto silencioso, em que se respeitava o distanciamento social. Nas ruas, não incomuns, são os relatos de pessoas se afastando (fisicamente) dos profissionais, pois os entendem como risco em meio à pandemia. Além disso, profissionais de enfermagem estão adoecendo e perdendo a vida pela covid-19 diariamente.

A pandemia traz a reflexão sobre as condições de trabalho das equipes de enfermagem em diversos ambientes. Em muitos casos, lugares precários, situações insalubres, sem acesso a Equipamentos de Proteção Individual 
(EPIs), com equipes subdimensionadas, realizando duplas jornadas de trabalho, salários miseráveis, enfrentando no seu cotidiano situações de assédio moral, conflitos éticos, sofrimento mental e exaustão física. Hoje o espaço dedicado, nas mídias sociais, enaltecendo a profissão, em que, carinhosamente, os profissionais são citados como heróis da saúde, já foi palco descredibilização à profissão. Mas com certeza os profissionais da enfermagem ao contrário de heróis, ou, até mesmo, "anjos de branco", não são invencíveis e imortais. Eles são tão humanos como qualquer outra pessoa, têm suas próprias fragilidades, necessitam de condições dignas de trabalho.

Enquanto um mundo inteiro ainda está em busca de vacinas que possam prevenir a doença e medicamentos para tratamento, a população em regime de isolamento social, assombrados por incertezas e medos, a enfermagem que é chamada à luta, para prestação de cuidado, aplicando seus saberes técnicos e científicos, evidencia sua prática, sai da invisibilidade e assume o papel que já é seu, protagonista no combate à covid-19.

Para que a valorização da enfermagem não seja apenas algo que também vai passar, é necessário que a discussão do papel protagonista do enfermeiro se amplie para além do enfrentamento da covid-19. Para além de gestos de respeito e carinho, a enfermagem necessita de apoio da sociedade e dos governantes para o reconhecimento da prática, não apenas nesse momento de luta contra a covid-19, mas, principalmente, depois, para que todo esse protagonismo no momento de pandemia não seja passageiro e sim transformador para profissão trazendo um real respeito, melhorias e conquistas.

\section{OBRAS CONSULTADAS}

WORLD HEALTH ORGANIZATION (WHO). Year of the nurse and the midwife. 2020. Disponível em: https://www.who.int/campaigns/year-of-the-nurse-and-the-midwife-2020. Acesso em: 16 jun. 2020. 